\title{
Pengaruh Keselamatan Dan Kesehatan Kerja Dan Lingkungan Kerja Terhadap Kinerja Karyawan Bagian Produksi Pada Perusahaan Tom's Silver Yogyakarta
}

\author{
Fx. Pudjo Wibowo') \\ Gregorius Widiyanto2) \\ Manajemen, Universitas Buddhi Dharma, Banten, Indonesia
}

\begin{abstract}
Abstrak
Tujuan dari penulisan ini adalah untuk mengetahui pengaruh keselamatan dan kesehatan kerja dan lingkungan kerja terhadap kinerja karyawan bagian produksi pada Perusahaan Tom's Silver Yogyakarta.. Penelitian dilakukan dengan menyebar kuensioner, sedang metode penelitian dengan menggunakan Simple Random Sampling. Uji t hitung diperoleh bahwa nilai $\mathrm{t}$ hitung keselamatan dan klesehatan kerja $2.699>t_{\text {tabel }} 1.665$ dan $.000<0.05$ dan nilai $t$ hitung lingkungan kerja $5.689 .>t_{\text {tabel }}$ 1.665 dan .000< 0.05 sehingga hipotesis yang menyatakan keselamatan dan kesehatan kerja dan lingkungan kerja berpengaruh positif secara parsial terhadap kinerja karyawan pada Perusahaan.Tom,s Silver Yogyakarta. Uji F , didapat F hitung $>$ $\mathrm{F}$ tabel atau $36.693>3.12$ atau tingkat signifikasi (sig) $0.000<0.05$ sehingga hipotesis yang menyatakan keselamatan dan kesehatan kerja dan konflik kerja secara bersama-sama berpengaruh terhadap kinerja karyawan pada Perusahaan Tom,s Silver Yogyakarta. Square $\left(R^{2}\right)$ menunjukkan koefisien determinasi yang berarti persentase kontribusi variabel independen. keselamatan dan kesehatan kerja dan lingkungan kerja memberikan sumbangan sebesar 67,7 \% terhadap kinerja karyawan pada Perusahaan.Tom,s Silver Yogyakarta.
\end{abstract}

Kata Kunci: Keselamatan dan kesehatan kerja, lingkungan kerja, dan kinerja Karyawan.

\section{ABSTRACT}

The purpose of this paper is to determine the effect of occupational safety and health and the work environment on the performance of employees in the production section of the Tom's Silver Yogyakarta Company. The study was conducted by distributing a questionnaire, while the research method using Simple Random Sampling. The t-test is obtained that the tvalue of work safety and health is 2.699> t table 1.665 and $.000<0.05$ and the t-value of the work environment is 5.689. $>t$ table 1,665 and .000 $<0.05$ so that the hypothesis which states that occupational safety and health and work environment has a positive positive effect on the performance of employees at the Company. Tom, s Silver Yogyakarta. F test, obtained F count $>$ F table or 36,693> 3.12 or significance level (sig) $0,000<0.05$ so that the hypothesis which states occupational safety and health and work conflict jointly affects the performance of employees at Tom's Company, Silver Yogyakarta. Square (R2) shows the coefficient of determination which means the percentage contribution of the independent variable. Occupational safety and health and work environment contributed $67.7 \%$ to the performance of employees at the Company. Tom, Silver Yogyakarta.

Keywords: Occupational safety and health, work environment, and employee performance.

\section{PENDAHULUAN}


Sumber daya manusia merupakan salah satu bagian yang berperan penting di dalam suatu organisasi, dengan hasil kinerja yang baik dari karyawannya maka tujuan perusahaan akan bisa dicapai sesuai dengan apa yang telah dirumuskan. Dalam suatu organisasi tidak semua kinerja yang dihasilkan karyawan / karyawan memperoleh hasil yang baik, sebab tingkat kinerja setiap orang itu berbeda-beda, karyawan / karyawan mempunyai cara sendiri untuk meningkatkan kinerjanya masing-masing. Karyawan merupakan sumber daya yang paling penting dalam perusahaan karena memiliki akal, bakat, tenaga, keinginan, pengetahuan, dan kreativitas yang sangat dibutuhkan oleh perusahaan untuk mencapai visi dan misi perusahaan. Seiring perkembangan ilmu pengetahuan dan teknologi canggih serta munculnya inovasi-inovasi baru dibidang teknik produksi, telah mendorong perusahaan untuk meningkatkan pengetahuan dan ketrampilan sumber daya manusianya, agar dapat menghasilkan produk yang berkualitas tinggi.

Proses produksi di perusahaan akan mengikuti perkembangan teknologi, sehingga proses berlangsung dengan cepat, efisien, dan menghasilkan produk yang bermutu. Penggunaan teknologi berpotensi menimbulkan resiko Keselamatan dan Kesehatan Kerja (K3). Perusahaan wajib memberikan perlindungan atas keselamatan dan kesehatan kerja sesuai amanat Undang-undang Nomor 13 tahun 2003 pasal 86, sehingga untuk meningkatkan produktivitas kerja tidak bisa mengabaikan keselamatan dan kesehatan karyawannya. Keselamatan dan Kesehatan Kerja (K3) sangat penting untuk diterapkan di perusahaan, khususnya pada bagian produksi agar terciptanya rasa aman dan nyaman dalam bekerja. Menurut Mangkunegara (2016), istilah K3 mencakup dua hal yaitu risiko keselamatan dan risiko kesehatan. Keselamatan kerja adalah suatu kondisi yang aman atau selamat daripenderitaan, kerusakan atau kerugian di tempat kerja. Sedangkan kesehatan kerja adalah suatu kondisi yang menunjukkan rasa bebas dari gangguan fisik, mental, emosi atau rasa sakit yang disebabkan oleh lingkungan kerja. Secara lebih rinci Mangkunegara (2016) menyebutkan adanya 5 indikator yang dapat mempengaruhi K3 yaitu keadaan tempat lingkungan kerja, pengaturan udara, pengaturan penerangan, pemakaian peralatan kerja, dan kondisi fisik dan mental pegawai. Secara umum, tujuan perusahaan menerapkan $\mathrm{K} 3$ adalah untuk meningkatkan produktivitas dan laba perusahaan yang selanjunya dapat dinikmati oleh pekerja dalam bentuk peningkatan gaji, kesejahteraan, dan tunjangan-tunjangan. Mangkunegara (2016) menyebutkan adanya beberapa tujuan (K3) secara lebih rinci, seperti agar setiap pegawai mendapat jaminan keselamatan dan kesehatan kerja baik secara fisik, sosial, dan psikologis.

Hubungan keselamatan dan kesehatan kerja (K3) dengan kinerja karyawan akan sangat menentukan kemajuan perusahaa, karena kondisi pekerjaan yang maksimal akan mempengaruhi hasil kinerjanya, terlebih perusahaan memberikan kenyamanan, jaminan keselamatan kesehatan kerja (K3), dan fasilitas yang memadahi dapat membuat karyawan dapat bekerja dengan tenang dan dapat mengerjakan tanggung jawabnya dengan baik dan maksimal. Keselamatan kesehatan kerja itu sangat penting karena tidak diperhatikannya secara serius maka akan mengakibatkan karyawan tidak nyaman bekerja dan hasilnya tidak akan efektif terhadap produk yang dihasilkan. 
Kecelakaan kerja sangat erat berhubungan dengan hubungan kerja diperusahaan. Hubungan kerja disini dimaksudkan adalah kecelakaan kerja yang terjadi dikarenakan oleh pekerja pada waktu melaksanakan pekerjaan. Ada banyak faktor dengan melakukan hubungannya dengan pekerjaan yang dapat mendatangkan kecelakaan bagi pekerja selain barang pecah belah yang yang digunakan, antara lain mesin dan peralatan, keadaan tempat kerja, dan lingkungan serta cara melakukan pekerjaan tersebut.

Perusahaan berupaya untuk meningkatkan kinerja seluruh karyawannya agar mampu bersaing dengan perusahaan lain karena dapat menghasilkan suatu barang atau jasa dengan cara yang lebih efisien. Kinerja merupakan tingkat keberhasilan seseorang secaara keseluruhan secara periode tertentu didalam melaksanakan tugas dibandingkan dengan berbagai kemungkinan seperti standart hasil kerja, target sasaran, atau kinerja yang ditentukan terlebih dahulu dan telah disepakati secara bersama. Hal ini dapat tercapai apabila perusahaan selalu memperhatikan faktor keselamatan kesehatan kerja ( K3) karena hal ini dapat meningkatkan kinerja karyawan.

Untuk meningkatkan kinerja karyawan agar dapat berkualitas dan bekerja dengan baik salah satu faktor terpenting yaitulingkungan kerja tempat karyawan tersebut bekerja. Dimana lingkungan kerja adalah kondisi-kondisi material dan psikologis yang ada dalam organisasi. Maka dari itu perusahaan harus menyediakan lingkungan kerja yang memadai seperti lingkungan fisik (tata ruang yang nyaman, lingkungan yang bersih, pertukaran udara yang baik, warna, penerangan yang cukup maupun musik yang merdu), serta lingkungan non fisik (suasana kerja karyawan, kesejahteraan karyawan, hubungan antar sesama karyawan, hubungan antar karyawan dengan pimpinan, serta tempat ibadah). Lingkungan kerja yang baik dapat mendukung pelaksanaan kerja sehingga karyawan memiliki semangat bekerja dan meningkatkan kinerja karyawan. Lingkungan kerja yang berada di sekitar karyawan perlu diperhatikan agar membawa dampak yang baik bagi kinerja seseorang.

Perusahaan harus dapat memperhatikan kondisi yang ada dalam perusahaan terutama pada bagian produksi, sehingga karyawan dapat bekerja dengan lancar dan merasa aman. Lingkungan kerja dalam suatu perusahaan sangat penting untuk diperhatikan manajemen. Meskipun lingkungan kerja tidak melaksanakan proses produksi dalam suatu perusahaan tetapi lingkungan kerja mempunyai hubungan langsung terhadap para karyawan yang melaksanakan proses produksi tersebut. Lingkungan kerja yang baik untuk karyawan dapat meningkatkan kinerja sebaliknya lingkungan kerja yang tidak baik dapat menurunkan kinerja karyawan. Kualitas lingkungan kerja dalam arti kondisi hubungan kerja yang nyaman dan sehat sangat mempengaruhi kesegaran dan semangat kerja karyawan.

Dari penjelasan diatas maka Keselamatan Kesehatan Kerja (K3) dan Lingkungan Kerja harus diperhatikan dan diterapkan pada Perusahaan Tom's Silver Yogyakarta, karena perusahaan ini bergerak di bidang produk-produk kerajinan perak maka masalah Keselamatan Kesehatan Kerja (K3) dan Lingkungan Kerja para karyawan sangat mempengaruhi kinerja karyawan.

\section{Perumusan Masalah :}


1. Seberapa besar pengaruh masing-masing variabel keselamatan dan kesehatan kerja dan lingkungan kerja terhadap terhadap kinerja karyawan bagian produksi Perusahaan Tom's Silver Yogyakarta?

2. Seberapa besar pengaruh scara bersama-sama variabel keselamatan dan kesehatan kerja dan lingkungan kerja terhadap kinerja karyawan bagian produksi Perusahaan Tom's Silver Yogyakarta?

\section{Tujuan Penelitian :}

1. Untuk menguji pengaruh keselamatan dan kesehatan kerja terhadap kinerja karyawan bagian produksi Perusahaan Tom's Silver Yogyakarta.

2. Untuk menguji pengaruh lingkungan kerja terhadap kinerja karyawan bagian produksi pada Perusahaan Tom's Silver Yogyakarta.

3. Untuk menguji pengaruh keselamatan dan kesehatan kerja dan lingkungan kerja terhadap kinerja karyawan bagian produksi pada perusahaan Tom's Silver Yogyakarta

\section{Manfaat Penelitian}

1. Bagi Perusahaan, penelitian ini berguna untuk mengetahui variabel-variabel yang mempengaruhi dan paling berpengaruh terhadap kinerja karyawan, sehingga dapat menjadi beban pertimbangan untuk memperoleh informasi yang lebih baik dalam usaha membangun guna mencegah persoalan keselamatan dan kesehatan kerja dan lingkungan kerja yang dihadapi karyawan sehingga dapat meningkatkan kinerja karyawan.

2. Bagi peneliti dapat dijadikan sarana informasi untuk meningkatkan wawasan dan pengetahuan tentang cara mengukur keselamatan dan kesehatan kerja dan lingkungan kerja dan factor dominan dalam meningkatkan kinerja karyawan.

3. Bagi akademis dan pembaca yang lain, dapat digunakan untuk pengembangan ilmu pengetahuan, menambah wawasan dan informasi gambaran bagaimana cara mengukur tingkat kinerja kerja karyawan dalam rangka peningkatan produktivitas karyawan suatu perusahaan.

\section{LANDASAN TEORI}

\section{Keselamatan kesehatan kerja ( K3 )}

Menurut Sri Rejeki dalam bukunya yang berjudul Sanitasi, Hygiene, dan K3 (2015 : 143) menyatakan bahwa : " Keselamatan Kesehatan kerja adalah suatu pemikiran dan upaya untuk menjamin keutuhan dan kesempurnaan, baik jasmaniah maupun rohaniah tenaga kerja pada khususnya, dan manusia pada umumnya, hasil karya untuk menuju masyarakat adil dan makmur". Menurut Kasmir (2016 : 266) dalam bukunya yang berjudul Manajemen Sumber Daya Manusia (Teori dan Praktik) menyatakan bahwa: "Keselamatan Kesehatan Kerja adalah aktivitas perlindungan secara menyeluruh dan upaya untuk menjaga karyawan jangan sampai mendapat suatu kecelakaan pada saat menjalankan aktivitasnya dan tetap sehat selama bekerja".

Arti penting dari keselamatan kesehatan kerja bagi perusahaan merupakan tujuan dan efesiensi perusahaan juga akan tercapai apabila semua pihak melakukan pekerjaaannya masing-masing dengan tenang dan tentram, tidak khawatir akan 
ancaman yang mungkin menimpa mereka. Kesehatan para pekerja dapat terganggu dengan penyakit, stres dalam bekerja, atau kecelakaan. Program kesehatan yang baik kakan menguntungkan para pekerja secara materil. Selain itu mereka dapat bekerja dalam lingkungan yang lebih nyaman sehingga secra keseluruhan para karyawan dapat bekerja lebih produktif, aktivitas perlindungan dan upaya untuk menjamin karyawan kerta keutuhan dan kesempurnaan, baik jasmaniah maupun rohaniah selama bekerja dan selalu dalam keadaan nyaman dan tidak mengganggu kinerja para pekerja.

\section{Lingkungan Kerja}

Lingkungan kerja dalam sbuah organisasi merupakan salah satu factor yang penting dalam menciptakan kinerja karyawan krena lingkungn kerja mempunyai pengaruh langsung terhadap karyawan dalm menyelesaikan pekerjan yang pada akhirny akan meningkatkan kinerja organisasi. Menurut Sihombing (2004) menyatakan liingkungan adalah dfaktor-faktor diluar manusia baik fisik non fisik dalam suatu organisasi. Faktor fisik ini ini mencakup peralatan kerja, suhu ditempat kerja, kesesakan dan kepadatan, kebisingan, luas ruang kerja, sedangkan non fisik mencakup hubungan kerja yang terbentuk instansi antara pimpinan dan bawahan serta antara sesame karyawan. Menurut Nitisemito (2000) lingkungan kerja adalah segala sesuatu yang ada disekitar para pekerja yang dapat mempengaruhi dirinya dalam menjalankan tugasnya yang telah diembankan.

Menurut Sedarmayani (2009) lingkungan kerja adalah keseluruhan alat perkakas dan bhan yang dihadapi lingkungan sekitar dimana seseorang bekerja, metode kerjanya, serta pengaturan kerjanya baik sebagai perseorangan maupun sebagai kelompok. Sedangkan menurut Sofyandi (2008) lingkungan kerja adalh lingkungan dimana pekerjanya melakukan pekerjaan setiap harinya. Lingkungan kerja yang kondusif memberikan rasa aman dan memungkinkan para karyawan untuk bekerja optimal.

\section{Kinerja}

Kinerja (prestasi kerja) adalah hasil kerja secara kualitas dan kuantitas yang dicapai oleh seseorang karyawan dalam melaksanakan tugasnya sesuai dengan tanggung jawab yang diberikan kepadanya (Mangkunegara, 2011:67). Kinerja mengacu kepada kadar pencapaian tugas-tugas yang membentuk sebuah pekerjaan karyawa. Kinerja merefleksikan seberapa baik karyawan memenuhi persyaratan sebuah pekerjaan (Simamora, 2004:339). Kinerja merupakan hasil atau keluaran dari suatu proses.

Kinerja karyawan merupakan suatu hal yang sangat penting dalam usaha perusahaan untuk mencapai tujuannya, sehingga berbagai kegiatan yang dilakukan perusahaan dengan memgkombinasikan antara usaha individu atau karyawan dengan tingkat kemampuan, keahlian dan pengalaman individu untuk meningkatkan kinerja karyawan

\section{Hipotesis}

Hipotesa ini masih merupakan dugaan sementara dan masih perlu diuji kebenarannya. 
$\mathrm{H}_{1}$ : Diduga keselamatan dan kesehatan kerja mempunyai pengaruh yang signifikan terhadap kinerja karyawan bagian produksi Perusahaan Tom,s Silver Yogyakarta

$\mathrm{H}_{2}$ : Diduga lingkungan kerja mempunyai pengaruh yang signifikan terhadap kinerja karyawan bagian produksi Perusahaan Tom,s Silver Yogyakarta

$\mathrm{H}_{3}$ : Diduga keselamatan dan kesehatan kerja, lingkungan kerja mempunyai pengaruh yang signifikan terhadap kinerja karyawan bagian produksi Perusahaan Tom,s Silver Yogyakarta

\section{METODE PENELITIAN}

Metode penelitian yang digunakan penulis adalah metode deskriptif. Metode deskriptif adalah suatu metode dalam meneliti status sekelompok manusia, suatu objek, suatu set kondisi, suatu sistem pemikiran, ataupun suatu kelas, peristiwa pada masa sekarang. Tujuan dari penelitian deskriptif ini adalah untuk membuat deskripsi, gambaran atau lukisan secara sistematis, factual dan akurat mengenai fakta-fakta, sifat-sifat serta hubungan antar fenomena yang diselidiki.

Dalam penelitian ini yang menjadi obyek penelitian mencakup keselamatan dan kesehatan kerja dan lingkungan kerja yang disebut dengan variabel bebas (independent variabel), sedangkan variabel tidak bebas (dependent variabel) dalam penelitian ini adalah kinerja karyawan bagian produksi Perusahaan Tom,s Silver Yogyakarta

\section{Lokasi Penelitian}

PERUSAHAAN TOM'S SILVER Yogyakarta Jln. Ngeksigondo No 60, Prenggan, Kota Gede, Kota Yogyakarta 55172

\section{Pengukuran Variabel}

Semua variabel yang digunakan dalam penelitian digunakan skala Likert (rentang nilai 1 sampai dengan 5) di mana jawaban responden di beri nilai sebagai berikut sangat setuju (SS) skor 5, setuju (S) skor 4 ragu-ragu skor 3, tidak setuju skor 2 dan sangat tidak setuju skor 1

\section{Populasi dan Sampel}

Populasi

Menurut Sugiyono (2011 : 80) dalam bukunya yang berjudul Metode Penelitian Kuantitatif Kualitatif dan R\&D menyatakan bahwa "Populasi diartikan sebagai wilayah generalisasi yang terdiri atas objek-objek yang mempunyai kualitas dan karakteristik tertentu yang ditetapkan oleh peneliti untuk dipelajari dan kemudian ditarik kesimpulannya".

Populasi dalam penelitian ini adalah karyawan bagian produksi PERUSAHAAN TOM'S SILVER Yogyakarta Jl. Ngeksigondo No 60, Prenggan Kota Gede Kota Yogyakarta.

\section{Sampel}

Menurut Sugiyono (2011 : 80) dalam bukunya yang berjudul Metode Penelitian Kuantitatif Kualitatif dan R\&D menyatakan bahwa "Sampel adalah bagian dari jumlah dan karakteristik yang dimiliki oleh populasi tersebut". Besarnya populasi dalam penelitian yang akan dilakukan, dan waktu terbatas yang dimiliki oleh peneliti, maka sampel yang diambil adalah sebanyak 40 orang. Sampel diambil 
secara Simple Random Sampling karena pengambilan anggota sampel dari populasi digunakan sebagai sampel tanpa memperhatikan strata yang ada dalam poplulasi itu.

\section{Uji Validitas Dan Realibilitas \\ Uji Validitas}

Uji validitas merupakan uji isntrumen data untuk mengetahui seberapa cermat suatu item dalam mengukur apa yang ingin diukur. Item dapat dikatakan valid jika adanya korelasi yang signifikan dengan skor totalnya, hal ini menunjukan adanya dukungan item tersebut dalam mengungkap suatu yang ingin diungkap. Item tersebut dapat berupa pertanyaan yang ditunjukan kepada responden dengan menggunakan kuisioner dengan tujuan untuk mengungkap sesuatu. Dalam pengujian ini metode analisis yang digunakan dalam uji validitas item adalah metode korelasi pearson. Teknik uji validitas dengan metode korelasi pearson yaitu dengan cara mengorelasikan skor item dengan skor totalnya. Skor total adalah penjumlahan seluruh item pada satu variabel. Adapun kriteria signifikasi pada pengujian ini adalah dengan menggunakan tingkat signifikasi, jika signifikasi $\leq 0,05$ maka item valid, tetapi jika signifikasi $\geq 0,05$ maka item tidak valid.

\section{Uji Reliabilitas}

Uji reliabilitas (reliability) merupakan kelanjutan dari uji validitas, dimana item yang masuk pengujian adalah item yang valid saja. Uji ini digunakan untuk mengetahui konsistensi alat ukur yang digunakan menggunakan kuisioner. Metode yang sering digunakan dalam penelitian adalah metode Cronbach Alpha. Adapun kriteria dalam pengujian reliabilitas adalah reliabilitas kurang dari 0,6 adalah kurang baik, sedangkan 0,7 dapat diterima dan diatas 0,8 adalah baik atau dinyatakan reliabel.

\section{Pengujian Asumsi Klasik}

\section{Uji Normalitas}

Bertujuan untuk menguji apakah dalam model regresi, variabel pengganggu atau residual memiliki distribusi normal. Penelitian ini menggunakan plot probabilitas normal (Normal probability plot) untuk menguji kenormalitasan jika penyebaran data (titik) disekitar sumbu diagonal dan mengikuti arah garis diagonal, maka model regresi memenuhi asumsi Normalitas.

\section{Uji Multikolinearitas}

Uji multikoniearitas bertujuan untuk menguji apakah model regresi ditemukan adanya korelasi antar variabel bebas (independen). Dalam model regresi yang baik seharusnya tidak terjadi korelasi diantara variabel bebas. Uji Multikolineritas dilakukan dengan melihat Tolerance dan Variance Inflasion Factor (VIF). Apabila nilai tolerance $<0.10$ atau sama dengan nilai VIF > 10. (Ghozali, 2010:91).

\section{Uji Autokorelasi}

Ada atau tidaknya autokorelasi ini dapat dilakukan dengan menggunakan uji statistic Durbin - Watson. Adapun dasar pengambilan keputusan dalam uji Durbin - Watson (Santoso, 2005), sebagai berikut, bila angka Durbin - Watson berada di bawah -2 , berarti autokorelasi, bila angka Durbin - Watson diantara -2 sampai +2, berarti tidak ada autokorelasi. dan bila angka Durbin - Watson di atas +2 , berarti ada autokorelasi negative. 


\section{Uji Heterokesdatisitas}

Uji Heterokesdatisitas digunakan untuk menguji apakah dalam sebuah regresi terdapat kesamaan varians dari residu dari satu pengamatan ke pengamatan yang lain sama. Cara mendeteksi heterokesdatisitas dalam penelitian ini dengan melihat pola sebaran grafik scatter plot. Jika ada pola tertentu, seperti titik yang ada berbentuk suatu pola tertentu yang teratur (bergelombang, melebar, kemudian menyempit ) maka telah terjadi heteroskedestisitas.

Metode Regesi Berganda

Metode regresi berganda merupakan studi mengenai keterangan variabel dependen dengan salah satu atau lebih variabel idenpenden, dengan tujuan untuk mengestimasi rata-rata populasi atau nilai rata-rata varibel dependen berdasarkan nilai variabel independen yang diketahui.

Data pengamatan biasanya tidak hanya disebabkkan oleh suatu variabel, melainkan oelh beberapa atau bahkan banyak variabel. Untuk itu peneliti menggunakan regresi linear berganda untuk menganalisis hubungan dan pengaruh suatu variabel terkait dengan dua atau lebih variabel bebas dengan rumus sebagai berikut:

$Y=a+b_{1} X_{1}+b_{2} X_{2}$

Dimana :

Y : kinerja karyawan

$\mathrm{X}_{1} \quad$ : keselamatan dan kesehatan kerja

$\mathrm{X}_{2} \quad$ : lingkungan Kerja

a : Nilai konstan

$b_{1}, b_{2}$ : Koefisien regresi

\section{Koefisien Determinasi ( $\left.\mathbf{R}^{2}\right)$}

Koefisien Determinasi $\left(\mathrm{R}^{2}\right)$ menunjukkan seberapa besar kemampuan independent (keselamatan dan kesehatan kerja, lingkungan kerja) menjelaskan variabel dependent (kinerja karyawan)

Uji t

Uji t bertujuan untuk mengetahui besarnya pengaruh masing-masing variabel bebas secara parsial/individu terhadap variabel terikatnya (V. Wiratna Sujarweni 2015) variabel bebas berpengaruh secara parsial terhadap variabel terikat secara signifikan bila nilai $t_{\text {hitung }}>t_{\text {tabel }}$

Uji F

Uji F digunakan untuk menguji apakah variabel bebas dalam penelitian ini mempunyai pengaruh secara simultan/bersama-sama terhadap variabel terikat dengan membandingkan nilai $\mathrm{F}_{\text {hitung }}>$ nilai $\mathrm{F}$ tabel

\section{ANALISIS DAN PEMBAHASAN}

Pada penelitian ini penulis mengambil beberapa orang atau responden untuk dijadikan sampel dalam menjawab pernyataan-pernyataan yang diajukan penulis mengenai analisis pengaruh keselamatan dan kesehatan kerja dan lingkungan kerja terhadap kinerja kerja karyawan bagian produksi pada Perusahaan Tom,s Silver Yogyakarta dalam bentuk beberapa pernyataan atau kuesioner yang diajukan kepada 40 orang atau responden. 


\section{Uji Validitas dan Uji Realibilitas}

\section{Uji Validitas}

Pengujian validitas tiap butir pertanyaan dalam penelitian ini dilakukan denganmengkorelasikan skor tiap butir dengan skor total. Dengan membandingkan nilai $r_{\text {hitung dengan } r} r_{\text {tabel. }}$ Jika $r_{\text {hitung }}>\mathrm{r}_{\text {tabel }}$ maka indikator dinyatakan valid.

Tabel 1. Uji Validitas Keselamatan dan kesehatan kerja, Lingkungan Kerja , dan kinerja Karyawan

\begin{tabular}{|c|c|c|c|}
\hline Butir Pertanyaan & $r_{\text {table }}$ & $\mathrm{r}$ hitungan & Keterangan \\
\hline $\mathrm{X}_{1.1}$ & 0,312 &, 526 & Valid \\
\hline $\mathrm{X}_{1.2}$ & 0,312 & 612 & Valid \\
\hline $\mathrm{X}_{1.3}$ & 0,312 & 315 & Valid \\
\hline $\mathrm{X}_{1.4}$ & 0,312 & ,539 & Valid \\
\hline $\mathrm{X}_{1} .5$ & 0,312 & 761 & Valid \\
\hline$X_{1} .6$ & 0,312 & 470 & Valid \\
\hline $\mathrm{X}_{1.7}$ & 0,312 & 620 & Valid \\
\hline$X_{1}, 8$ & 0,312 & ,398 & Valid \\
\hline$X_{1} .9$ & 0,312 & 634 & Valid \\
\hline$X_{1.10}$ & 0,312 & 453 & Valid \\
\hline$X_{2.1}$ & 0,312 & 827 & Valid \\
\hline$X_{2.2}$ & 0,312 & 816 & Valid \\
\hline$X_{2.3}$ & 0,312 & 747 & Valid \\
\hline$X_{2.4}$ & 0,312 & 714 & Valid \\
\hline$X_{2.5}$ & 0,312 & 835 & Valid \\
\hline$X_{2.6}$ & 0,312 & 760 & Valid \\
\hline$X_{2.7}$ & 0,312 & ,509 & Valid \\
\hline$X_{2,8}$ & 0,312 & 668 & Valid \\
\hline$X_{2.9}$ & 0,312 & 777 & Valid \\
\hline$X_{2.10}$ & 0,312 & 712 & Valid \\
\hline Y.1 & 0,312 & 797 & Valid \\
\hline Y.2 & 0,312 & 879 & Valid \\
\hline Y.3 & 0,312 & 728 & Valid \\
\hline Y.4 & 0,312 & 849 & Valid \\
\hline Y.5 & 0,312 & 732 & Valid \\
\hline Y.6 & 0,312 & 694 & Valid \\
\hline Y.7 & 0,312 & 920 & Valid \\
\hline$Y, 8$ & 0,312 & 830 & Valid \\
\hline Y.9 & 0,312 & 559 & Valid \\
\hline Y.10 & 0,312 & 570 & Valid \\
\hline
\end{tabular}

Sumber : Data diolah

Tabel 1. menunjukkan bahwa setiap item pertanyaan keselamatan dan kesehatan kerja, lingkungan kerja, dan kinerja karyawan semuanya valid karena nilai $\mathrm{r}$ hitung $>$ $r$ tabel 


\section{Uji Realibilitas}

Uji realibilitas dilakukan untuk menilai konsistensi dari instrument penelitian. Instrument dapat dikatakan realibel jika nilai Cronbach's Alpha > nilai a =0,70.

Tabel 2. Hasil Uji Reliabilitas

\begin{tabular}{|l|l|l|}
\hline \multicolumn{1}{|c|}{ Variabel } & \multicolumn{1}{|c|}{ Cronbach's Alpha } & \multicolumn{1}{c|}{ Keterangan } \\
\hline Keselamatan dan kesehatan & 0.838 & Reliabel \\
kerja & & Reliabel \\
Lingkungan kerja & .0 .932 & Reliabel \\
Kinerja Karyawan & 0.938 &
\end{tabular}

Sumber : Data diolah

Tabel 2 menunjukkan bahwa semua pernyataan yang digunakan dalam variabel ini adalah reliabel.

\section{Pengujian Uji Asumsi Klasik}

\section{a. Hasil Uji Normalitas Data}

Uji Normalitas data adalah merupakan gambal visual yang menunjukkan jauh dekatnya titik-titik pada gambar tersebut dengan garis diagonal, jika data yang berasal dari distribusi normal, maka nilai-nilai sebaran data yang tercermin dalam titik-titik pada ouput akan terletak di sekitar garis diagonal, sebaliknya jika data berasal dari distribusi yang tidak normal maka titik-titik tersebut tersebar tidak di sekitar garis diagonal (terpencar jauh dari garis diagonal (terpencar jauh dari garis diagonal)

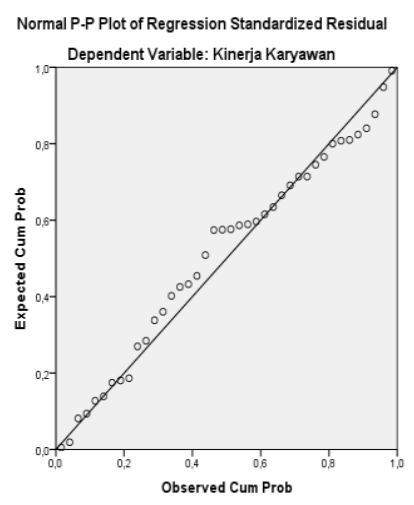

Gambar 1. Hasil Uji Normalitas Menggunakan Grafik P.Plot

Gambar 1 menunjukkan bahwa data tersebar di sekeliling garis diagonal dan tidak terpencar jauh dari garis diagonal, dan melihat titik-titik yang mengikuti arah garis linier dari kiri ke bawah ke kanan atas. Dan dapat disimpulkan bahwa model dalam penelitian ini memenuhi persayaratan normalitas data.

b. Hasil Uji Multikolinerieritas

Suatu model regresi dikatakan dari masalah multikolinearitas dengan Cara mengetahui ada atau tidaknya gejala multikolinieraritas antara lain dengan melihat nilai variance inflation factor (VIF) dan tolerance, apabila nilai VIF kurang 
dari 10 dan Tolerance lebih dari 0,1 maka dinyatakan tidak terjadi multikoliniearitas.

Tabel 3. Uji Multikolineritas

\begin{tabular}{|l|r|r|ll|}
\hline \multicolumn{1}{|c|}{ Variabel } & Tolerance & \multicolumn{2}{|c|}{ VIF } & \multicolumn{2}{|c|}{ Keterangan } \\
\hline $\begin{array}{l}\text { Keselamatn dan kesehatan } \\
\text { kerja }(\mathrm{X} 1)\end{array}$ & .722 & 1.386 & $\begin{array}{l}\text { Tidak } \\
\text { Multikolinearitas }\end{array}$ & terjadi \\
\hline Lingkungan Kerja (X2) & .722 & 1.386 & $\begin{array}{l}\text { Tidak } \\
\text { Multikolinearitas }\end{array}$ \\
\hline
\end{tabular}

Tabel 3 menunjukkan bahwa variabel keselamatan dan kesehatan kerja (X1) dan lingkungan kerja (X2) tidak terjadi multikoliniearitas karena nilai VIF kurang dari 10 dan Tolerance lebih dari 0,1

c. Hasil Uji Autokorelasi

Ada atau tidaknya autokorelasi ini dapat dilakukan dengan menggunakan uji statistic Durbin - Watson. Adapun dasar pengambilan keputusan dalam uji Durbin - Watson (Santoso, 2005), sebagai berikut, bila angka Durbin - Watson berada di bawah -2 , berarti autokorelasi, bila angka Durbin - Watson diantara -2 sampai +2 , berarti tidak ada autokorelasi.

dan bila angka Durbin - Watson di atas +2 , berarti ada autokorelasi negatif, dari perhitungan hasil output SPSS persamaan regresi dalam penelitian ini dimana DW (Durbin-Watson), sebesar 2.602, untuk nilai dL adalah 1.3908 dan nilai dU adalah 1.6000 , maka nilai $4-\mathrm{dU}=2,4000$ dan $4-\mathrm{dL}=2.6092$, hal dapat disimpulkan berarti model regresi diatas tidak terdapat masalah autokorelasi.

d. Uji Heteroskedastisitas

Dasar pengambilan keputusan dalam analisis heteroskedastisitas adalah sebagai berikut (Santoso, 2005), Jika ada pola tertentu, seperti titiktitik yang ada membentuk pola tertentu yang teratur (bergelombang, melebar kemudian menyempit), maka sudah menunjukkan telah terjadinya gejala heteroskedastisitas dan Jika tidak ada pola yang jelas, serta titik-titik menyebar diatas dan di bawah angka 0 pada sumbu $Y$, maka tidak terjadi heteroskedastisitas.

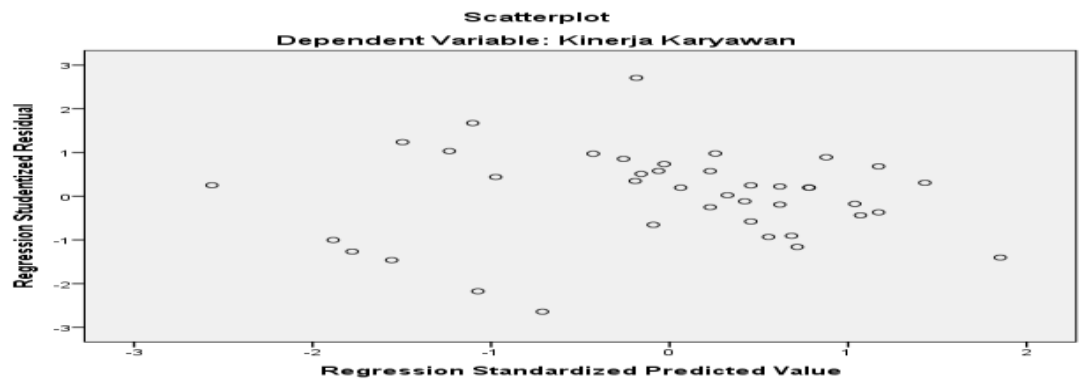

Gambar 2. Grafik Scatterplot

Gambar 2 menunjukkan bahwa titik-titik yang dihasilkan menyebar secara acak dan tidak membentuk pola atau trend garis tertentu dan data tersebut tersebar diatas dan dibawah angka 0 sehingga model regresi layak digunakan untuk memprediksi kinerja karyawan berdasarkan variabel yang mempengaruhi yaitu keselamatan dan kesehatan kerja dan lingkungan kerja

\section{Analisis Linier Berganda}


Untuk mengetahui ada tidaknya hubungan antara variabel $X_{1}$ (keselamatan dan kesehatan kerja), variabel $\mathrm{X}_{2}$ (lingkungan kerja ), terhadap $\mathrm{Y}$ (kinerja karyawan), serta mengukur kuat tidaknya hubungan tersebut, maka digunakan analisa regresi berganda dengan perhitungan SPSS (Statistical Package Service Softition), Versi 20.0,

Tabel 4.

Hasil Perhitungan Regresi Berganda

\begin{tabular}{|l|r|r|r|}
\hline \multicolumn{1}{|c|}{ Variabel } & Koefisien Regresi & \multicolumn{1}{c|}{ T hitung } & \multicolumn{1}{c|}{ Sig } \\
\hline Konstanta & 5.145 & .874 & .388 \\
\hline $\begin{array}{l}\text { Keselamatan dan kesehatan kerja } \\
\left(\mathrm{X}_{1}\right)\end{array}$ & .454 & 2.699 & .010 \\
\hline Lingkungan ker( $\left.\mathrm{X}_{2}\right)$ & .672 & 5.689 & .000 \\
\hline $\begin{array}{l}\text { F hitung : } 38.693 \\
\text { Sig }: 0.000\end{array}$ & & & \\
\hline Adjusted R2 :0.659 $: 0.823$ & & & \\
\hline $\mathrm{R} \quad$ & & \\
\hline
\end{tabular}

Sumber : Data diolah

Berdasarkan tabel 4 diatas dapat dibentuk persamaan regresi berganda :

$Y=5,145+0,454 X_{1}+0,672 X_{2}+\ldots \beta$

Persamaan tersebut mempunyai arti sebagai berikut:

1. Nilai konstanta (a) positif 5.145menunjukkan besarnya kinerja karyawan pada Perusahaan Tom,s Silver Yogyakarta, jika tidak ada variabel keselamatan dan kesehatan kerja, lingkungan kerja adalah positif 5.145 satuan.

2. Nilai koefisien regresi $\left(b_{1}\right)$ variabel stress kerja positif sebesar 0.454 berarti terdapat pengaruh positif dari variabel keselamatan dn kesehatan kerja terhadap kinerja karyawan pada Perusahaan Tom,s Silver Yogyakarta 0.454 dengan asumsi variabel lainnya tetap atau konstan.

3. Nilai koefisien regresi $\left(b_{2}\right)$ variabel lingkungan kerja positif sebesar 0.672 berarti terdapat pengaruh positif dari variabel lingkungan kerja terhadap kinerja karyawan pada Perusahaan Tom,s Silver Yogyakarta sebesar 0.672 dengan asumsi variabel lainnya tetap atau konstan.

Uji $\mathbf{t}$

Tabel 5. Uji t

Coefficients $^{\mathrm{a}}$

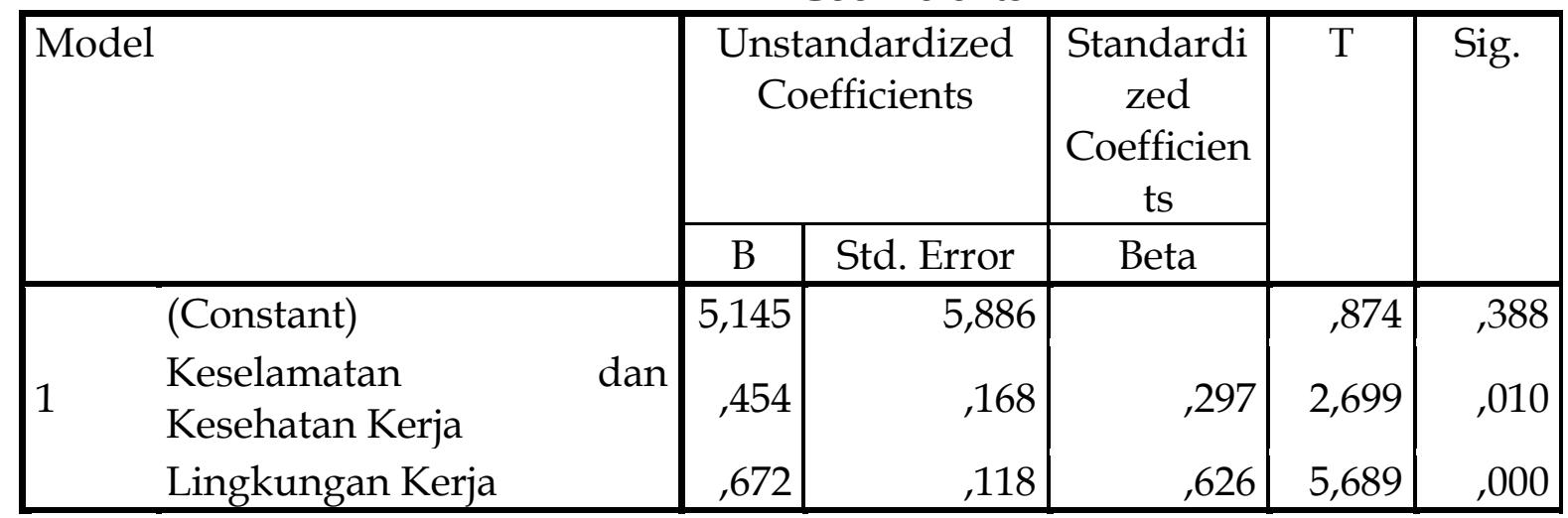

a. Dependent Variable: Kinerja Karyawan

Sumber : Hasil Olahan SPSS 20 
Tabel 5 menunjukkan bahwa :

a. Variabel keselamatan dan kesehatan kerja secara parsial berpengaruh positif dan signifikan (nilai $t$ hitung keselamatan dan kesehatan kerja $2.699>t_{\text {tabel }} 1.686$ dan $.000<0.05$ terhadap kinerja Karyawan pada Perusahaan Tom,s Silver Yogyakarta.

b. Variabel lingkungan kerja secara parsial berpengaruh positif dan signifikan (nilai $t$ hitung lingkungan kerja $5.689>t_{\text {tabel }} 1.686$ dan $.000<0.05$ terhadap kinerja karyawan pada Perusahaan Tom,s Silver Yogyakarta.

\section{Uji F}

Tabel 6. Tabel F

ANOVAa $^{\mathrm{a}}$

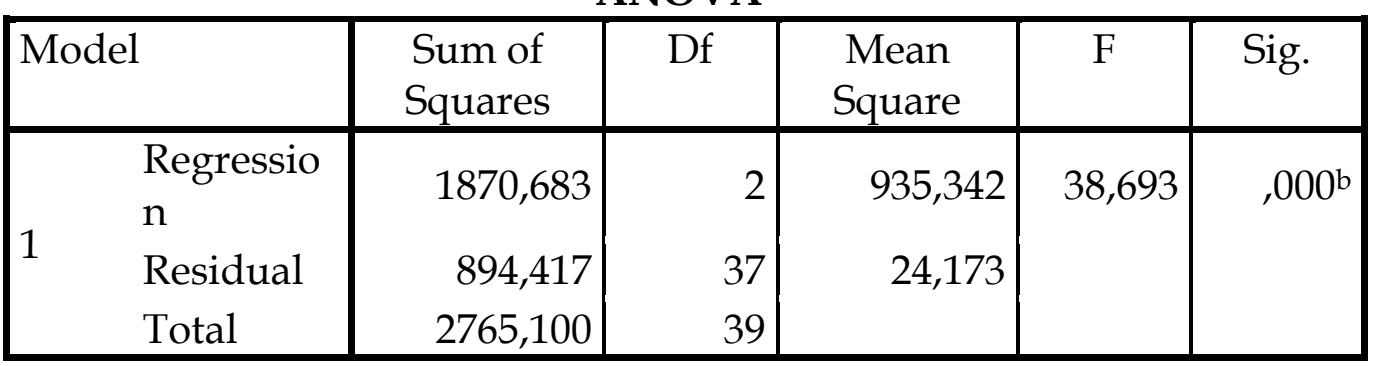

a. Dependent Variable: Kinerja Karyawan

b. Predictors: (Constant), Lingkungan Kerja , Keselamatan dan Kesehatan Kerja

Sumber : Hasil Olahan SPSS 20

Tabel 6 menunjukkan bahwa nilai $\mathrm{F}$ hitung sebesar 36.693 dengan nilai signifikansi sebesar 0.000 sehingga nilai $F$ hitung $>F_{\text {tabel }}$ atau $36.693>3.25$ atau tingkat signifikasi (sig) $0.000<0.05$, maka dapat disimpulkan berpengaruh secara simultan (bersamasama) antara keselamatan dan kesehatan kerja dan lingkungan kerja, terhadap kinerja karyawan pada Perusahaan Tom,s Silver Yogyakarta.

Uji $\mathbf{R}$ dan $\mathbf{R}^{2}$

Tabel 7 Uji R dan $\mathrm{R}^{2}$

Model Summaryb

\begin{tabular}{|c|c|c|c|c|c|c|c|c|c|}
\hline \multirow{2}{*}{$\begin{array}{l}\text { Mod } \\
\text { el }\end{array}$} & \multirow[t]{2}{*}{$\mathrm{R}$} & \multirow{2}{*}{$\begin{array}{c}\mathrm{R} \\
\text { Square }\end{array}$} & \multirow{2}{*}{$\begin{array}{c}\text { Adjuste } \\
\text { d R } \\
\text { Square }\end{array}$} & \multirow{2}{*}{$\begin{array}{l}\text { Std. Error } \\
\text { of the } \\
\text { Estimate }\end{array}$} & \multicolumn{5}{|c|}{ Change Statistics } \\
\hline & & & & & $\begin{array}{l}\text { R Square } \\
\text { Change }\end{array}$ & $\begin{array}{c}\mathrm{F} \\
\text { Change }\end{array}$ & df1 & $\mathrm{df} 2$ & $\begin{array}{c}\text { Sig. F } \\
\text { Chang } \\
\text { e }\end{array}$ \\
\hline 1 & $823^{\mathrm{a}}$ & 677 & 659 & 4,917 & 677 & 38,693 & 2 & 37 & ,000 \\
\hline
\end{tabular}

a. Predictors: (Constant), Lingkungan Kerja , Keselamatan dan Kesehatan Kerja

b. Dependent Variable: Kinerja Karyawan

Sumber : Hasil Olahan SPSS 20

Dari tabel 7 menunjukkan bahwa :

1. Kolom $\mathrm{R}$ menunjukkan angka koefisien korelasi sebesar 0,823 . Hal ini berarti pengaruh antara keselamatan dan kesehatan kerja dan lingkungan kerja dengan kinerja karyawan adalah cukup kuat.

2. Kolom $\mathrm{R}$ Square sebesar 0,677 Hal ini menunjukkan besarnya pengaruh keselamatan dan kesehatan kerja dan lingkungan kerja terhadap kinerja karyawan 
adalah $67,7 \%$, sedangkan sisanya $(100 \%-67,7 \%=32,3 \%)$ dipengaruhi oleh faktorfaktor lain. R Square berkisar pada 0 sampai 1, semakin besar R Square maka semakin kuat hubungan antara keselamatan dan kesehatan kerja dan lingkungan kerja dengan kinerja karyawan atau sebaliknya.

\section{KESIMPULAN DAN SARAN}

Berdasarkan penelitian studi empiris yang dilakukan mengenai analisis pengaruh keselamatan kesehatan kerja dan lingkungan kerja terhadap kinerja karyawan pada Perusahaan Tom,s Silver Yogyakarta, hasil yang diperoleh dengan menggunakan regresi linier berganda diperoleh hasil sebagai berikut:

1. Uji validitas dan uji Reliabilitas menunjukkan bahwa semua item pertanyaan dari variabel keselamatan dan kesehatan kerja $\left(\mathrm{X}_{1}\right)$, lingkungan kerja $\left(\mathrm{X}_{2}\right)$ dan kinerja karyawan $(\mathrm{Y})$ diterima atau semua pertanyaan yang diajukan kepada responden adalah valid dan reliable.

2. Uji $t$ hitung didapat nilai $t$ hitung keselamatan dan klesehatan kerja $2.699>t_{\text {tabel }}$ 1.665 dan $.000<0.05$ dan nilai $t_{\text {hitung }}$ lingkungan kerja $5.689 .>t_{\text {tabel }} 1.665$ dan $.000<0.05$ sehingga hipotesis yang menyatakan keselamatan dan kesehatan kerja dan lingkungan kerja berpengaruh positif secara parsial terhadap kinerja karyawan pada Perusahaan Tom,s Silver Yogyakarta.

3. Uji $F$, didapat $F$ hitung $>F$ tabel atau $36.693>3.12$ atau tingkat signifikasi (sig) 0.000 $<0.05$ sehingga hipotesis yang menyatakan keselamatan dan kesehatan kerja dan konflik kerja secara bersama-sama berpengaruh terhadap kinerja karyawan pada Perusahaan Tom,s Silver Yogyakarta.

4. Berdasarkan hasil koefisien determinasi menunjukkan bahwa keselamatan dan kesehatan kerja dan lingkungan kerja memberikan sumbangan sebesar 67,7 \% terhadap kinerja karyawan pada Perusahaan Tom,s Silver Yogyakarta

\section{Saran}

1. Pengaruh keselamatan kesehatan kerja pada Perusahaan Tom,s Silver Yogyakarta disisi pelatihan yang berkesinambungan penggunaan peralatan produksi membuat kinerja lebih baik dan kelengkapan peralatan yang memadahi dapat membuat karyawan kinerja karyawan menjadi lebih nyaman dan dapat menyelesaikan dengan apa yang sudah di targetkan dan bekerja sesuai dengan mutu yang telah ditetapkan oleh perusahaan.

2. Perlu ditingkatkan lingkungan kerja yang lebih baik lagi agar pegawai lebih puas dalam bekerja seperti menyediakan tempat yang memadai untuk melaksanakan pekerjaan dan rutinitas sehari-hari, jaminan rasa aman dan nyaman ketika sedang bekerja ditempat kerja serta hubungan yang baik diantara kelompok kerja sehingga tercapai sasaran organisasi dengan lebih maksimal.

3. Kinerja Karyawan Perusahaan Tom,s Silver Yogyakarta perlu dikembangkan lagi dengan dilakukan pelatihan yang berkesimbungan, hal ini guna meningkatkan kemampuan karyawan dalam bekerja nanti

\section{Daftar Pustaka}


Alex Nitisemito, 2000, Manajemen Personalia, Ghalia Indonesia, UGM, Yogyakarta Arivia Ruli Ardiansari, Sri Haryani (2018), Pengaruh K3, Komitmen Organiasasi Dan Motivasi Kerja Terhadap Produktivitas Kerja Karyawan PT Adi Satria Abadi Yogyakarta, Efektif Jurnal Bisnis dan Ekonomi, Volume 9, No 1, Juni 2018, ISSN :2087-1872 E-ISSN: 2503-2968

Eka Ristiani, 2015, Pengaruh Kesehatan \& Keselamatan Kerja Dan Lingkungan Kerja Terhadap Kinerja Karyawan Bagian Produksi Pada PT Surya Bratasena Plantation Pelalawan, FEKON, Vol.2 No.1 Februari 2015, Faculty Of Economi Riau University, Pekanbaru Indonesia

Ghozali, Imam, 2006, Aplikasi Analisis Multivariat dengan SPSS, Badan Penerbit Universitas Diponegoro, Semarang

Kasmir, 2016, Manajemen Sumber Daya Manusia (Teori Dan Praktik). Jakarta : Pt. Raja Grafindo Persada

Liana Ambarsari, Pengaruh Lingkungan Kerja dan Keselamatan Kesehatan Kerja Terhadap Kinerja Karyawan Pada PT Total Bangun Persada Tbk, Naskah Publikasi, Program Studi Manajemen Fakultas Ekonomi dan Bisnis Universitas Muhammadiyah Surakarta, 2015

Mangkunegara, Anwar Prabu., 2011, Manajemen Personalia, Edisi Ketiga, Gajah Mada University Press, Yogyakarta.

Mangkunegara, Anwar Prabu., 2016, Manajemen Sumber Daya Manusia Perusahaan, Bandung: Remaja Rosda Karya

Rejeki, Sri, 2015, Sanitasi Hygiene Dan K3, Bandung : Rekayasa Sains

Santoso, Singgih, 2005 SPSS Mengolah Data Statistik Secara Profesional, Penerbit PT Elek Media Komputindo Kelompok Gramedia, Jakarta

Sugiyono, 2011, Metode Penelitian Kuantitatif, Kualitatif dan R \& D Bandung: Alfabeta.

Sujarweni, W., 2015, Metologi Penelitian Bisnis dan Ekonomi, Yogyakarta : Pustaka Baru Press

Sedamayanti, 2009, Sumber Daya Manusia dan Produktivitas, Bandung, CV. Mandar Maju,

Sihombing, 2004, Pengaruh Keterlibatan dalam Pengambilan Keputusan, Penilaian Pada Lingkungan Kerja dan Motivasi Berprestasi Terhadap Kepuasan Kerja Pamong Pelajar,http://www,depdiknas.go.id.Diakses: 2 Juni 2011

Simamora, H.,2004, Manajemen Sumber Daya Manusia, Penerbit Graha Ilmu, Yogyakarta

Sofyandi, Herman, 2008, Manajemen Sumber Daya Manusia, Yogyakarta : Penerbit Graha Ilmu 